\title{
Vernon Lee's Problem with Landor
}

\section{THE STYLE AND THE MAN}

Vernon Lee's only book devoted entirely to the theory and criticism of literature, The Handling of Words, appeared in January 1923. ${ }^{1}$ It was reprinted as early as March of the same year, and once more before the year was out. Later it became one of the handful of Lee's books which made it into John Lane's 'Week-End Library' series, a popular pocket-sized format, appearing in this edition in 1927. It would therefore seem to have been one of her better-known books in the decade or two after its publication, and it has received a significant proportion of the scholarly interest directed towards her non-fiction in more recent times. ${ }^{2}$ Like many of Lee's other books, this one was made up of various essays written over a considerable length of time; and the chapter which alone forms my prime subject had originally been published twenty years earlier. It comes from a group of three essays collectively entitled 'Studies in Literary Psychology', which first appeared in The Contemporary Review, as a series running from 1903 into 1904. The second of these, discussing 'The Rhetoric of Landor', became chapter V(b) in The Handling of Words. ${ }^{3}$

Walter Savage Landor (1775-1864), whose canonical status is lower now than it has been at any other time since he hit his stride in about 1798, has meant various things to various people. The quality, or set of qualities, for which he has been taken to stand have been called by various names, and submitted to varying critical evaluations; but Landor is eminent for having always been an author invoked as a model of certain stylistic values, and therefore a focus for arguments about literary taste. His readersip was never large: Sidney Colvin began his 1882 study of Landor with the averral that 'Few men have ever impressed their peers so much, or the general public so little'. ${ }^{4}$ Still, the scope of his readership does seem to have begun diminishing gradually from about the start of the twentieth century, the diminution accelarating in the post-war period until, by now, he is hardly read at all.

It was at the beginning of this process of decline that Vernon Lee (1856-1935) expressed her frustration with Landor's famous style. To her Landor was, in the final analysis, 'an unfeeling wretch'. The charges brought seem simple enough at first sight, but reveal, upon closer attention, considerable complexity, some ambiguity, and an interesting intellectual history. In many ways her assessment would seem to make explicit the reasons for Landor's decreasing popularity with readers generally. And yet it also shows Lee's distance from some of the dominant critical tastes of the literary intelligentsia of her own time-not only of the rising generation of 'Modernists' and 'New Critics', but even those who had been her contemporaries in the late nineteenth century. The clash of values between Landor and Lee is not as neatly emblematic as the historian of taste might inititally hope, but instead discloses complexities of thought and 'feeling' which have more than historical interest.

My intention is to attend with some care to Lee's analysis of Landor, and to examine closely the grounds for her judgements. This may seem a modest aim, compared with other scholars' attempts to offer accounts of Lee's critical theory in

\footnotetext{
${ }^{1}$ Vernon Lee, The Handling of Words and other Studies in Literary Psychology (London 1923).

${ }^{2}$ It has also been republished twice in critical editions: one intr. by Royal A. Gettmann (Lincoln, Nebraska, 1968); the other ed. and intr. by David Seed (Lewistown 1992).

${ }^{3}$ First publication was in The Contemporary Review 84 (Dec. 1903), 856-64.

${ }^{4}$ Sidney Colvin, Landor (London 1882) p. 1.
} 
the round $;^{5}$ but I believe that the questions raised by such an apparently limited enquiry are important ones for the modern critic as well as for the historian of criticism: questions about the ideal functions of both creative and critical writing. Vernon Lee was an acute reader, most of whose observations remain valid and illuminating, even if modern scholars may not feel able to share her values or follow so far as her conclusions. Christa Zorn, for example, thinks that Lee was too 'heavily burdened by the Victorian heritage of normative evaluations', remarking, in an otherwise appreciative study, her 'unblushing Victorian judgmentalism' and even 'Victorian smugness'. Irony notwithstanding, such comments would seem to presuppose not only a stereotype of the 'Victorian' but also a normative view of what modern criticism is supposed to do, and against which Lee is unfairly evaluated. In any case, the characteristics identified by Zorn, which make Lee's criticism 'antiquated and, at times, rather annoying', are such that sympathetic modern readers, in her view, must try to 'ignore' them. ${ }^{6}$ Taking Lee seriously as a critic, without having to make these allowances, should help us, I hope, to rationalize not only her own structures of thought, but also their connections with the systems and habits of other critics - especially Walter Pater, whose influence upon serious thinkers about culture, art and morality has not always been impartially understood in recent scholarship. Her arguments may cast a different light, too, over some of the critical ideas we know well, and perhaps inherit, from the idioms of 'Modernism'. To read her with Eliot or Pound in the back of one's mind can prompt valuable reflectionsregarding the relation of rhetoric to poetry, for example; or the place of 'sincerity' in literature; or what we mean, and what might be meant, in speaking of the 'objective' and 'subjective'. Furthermore, in the present period of critical history, when it is a little uncertain whether or not 'the Author' has actually died, The Handling of Words might provoke us to think again, in usefully unfamiliar terms, about what our assumptions really are concerning the roles of personality and temperament in literature.

Lee's stated aim in 'The Rhetoric of Landor' is to test the thesis that 'even the most purely "artistic" writing is determined by the underlying temper of the man who writes', and to see how far 'this same so-called artistic quality is in reality the result of very human qualities or defects' (p. 158). Landor, as the paradigmatic 'classical' stylist, is taken to exemplify what is here called 'artistic' writing; that is, writing governed to the highest degree by premeditated, acquired and controlled techniques of stylistic artifice, for 'literary' or aesthetic purposes. A reader might reasonably consider such writing to be comparatively impersonal, because conventionalized. Lee sets out to show that, on the contrary, Landor's style arises directly from his 'human qualities or defects'. After all, these are 'Studies in Literary Psychology', and in the preamble to this group of essays Lee has already explained the origins of her enquiry in the notion-

that there may be some necessary connection between the structure of a man's sentences and his more human characteristics; and that style, in so far as it is individual, is but a kind of gesture or gait, revealing, with the faithfulness of an unconscious habit, the essential peculiarities of the Writer's temperament and modes of being. (p. 136).

The emphasis on 'temperament' - on the unconscious formal and stylistic

\footnotetext{
${ }^{5}$ A recent overview is Christa Zorn, 'The Handling of Words: Reader Response Victorian Style', in Vernon Lee: Decadence, Ethics, Aesthetics, ed. Catherine Maxwell and Patricia Pulham (Basingstoke 2006) pp. 174-92.

${ }^{6}$ Ibid., pp. 176, 178, 182.
} 
manifestations, in the artistic object, of the maker's subjective 'modes of being' - is broadly but palpably Paterian. In a certain aspect it appears simply to continue, into the realm of the unconscious and half-conscious functions of literary manner, the kind of thinking typified by Pater's 'Essay on Style'. If 'the style is the man', Pater places much emphasis, both in that essay and elsewhere, on 'selection' and 'selectiveness'; and although he is often interested in the mysterious origins of aesthetic preferences, in the operations of 'temperament' and its development, nevertheless his notion of style focusses attention largely on what seem to be eminently conscious decisions. ${ }^{7}$ Lee's idea of style as a reliable revelation of character precisely because it is an 'unconscious habit', only changes the accent somewhat.

Another thing to consider with regard to Lee's distinction between the 'artistic' qualities of style and the stylist's 'human' characteristics, is the space which this opens up for moral judgement. The application of moral criteria to aesthetic characteristics has always brought with it theoretical difficulties; but if one can track some elements of style back to human characteristics, understood to impinge inevitably upon the work, then moral judgement becomes easier: unlike the category of the 'aesthetic', the 'human' is the natural realm of morality. And readers of The Handling of Words will already be able to guess at Lee's attitude to Landor's moral character before they have even reached the fifth chapter, because in an earlier section of the book we find her meditating the problem of 'literary talent' -

\begin{abstract}
A thing most difficult of definition, because the order of the universe, finding it vain in itself, has on the whole not given it a chance when separated from the human worth of the Writer. Yet we occasionally get a glimpse of it; [e.g.] when the mere poverty of thought and feeling, the vacuity of the man, as in Gautier, d'Annunzio and, I grieve to say, Swinburne and Landor, show it through rents and threadbareness [...] (p. 126).
\end{abstract}

Landor is to be considered one of the writers in whom literary talent and human worth are furthest apart, or most cleanly divisible: he has great artistic qualities, but displays 'poverty of thought and feeling'.

Arriving at the essay itself, we find Landor presented as 'an unfeeling wretch' —or at least 'an unfeeling wretch as soon as he dealt with pen and ink'. Here, then, there is a further distinction: between the human worth of the 'man' as man, and that of the 'man' as man-of-letters. 'I have nothing to do with what Landor may have been capable, or not, of feeling under the stress of reality', she says; but she feels able to demonstrate beyond doubt 'that he was an unfeeling wretch as soon as he dealt with pen and ink, his own or others' ', (p. 173). It is in the roles of reader and writer that he falls short.

As a writer, Lee complains, Landor 'does not allow us to feel, so anxious is he that we should define and determine'. Here the compaint is not that Landor does not himself feel (although it may amount to that), but that he prevents the reader from feeling. And it is precisely his stylistic fastidiousness which gets in the way. Here is the example she adduces:

Could she (Sappho) be ignorant that shame and fear seize it (love) unrelentingly by the throat, while hard-hearted impudence stands at ease, prompt at opportunity, and profuse in

\footnotetext{
${ }^{7}$ See Pater's 'Essay on Style' in Appreciations, Library edn (London 1910) pp. 5-38, esp. pp. 15-18, 26, 29-32. See also 'A Prince of Court Painters', in Imaginary Portraits, Library edn (London 1910) pp. 6, 23, 22-23. [Appreciations first published in 1889, Imaginary Portraits in 1887.]
} 
declaration $?^{8}$

'In this passage', Lee writes, 'lucidity is obtained by the distinction between prompt and profuse. But in the meantime poor Timid Love, who, after all, should have been the hero of the play, is forgotten!' Syntactical lucidity, the well-balanced sentence, is a merit in itself, but for Lee it must never distract attention from the feeling. She makes a similar criticism of another passage, 'one of his finest', she says, 'and one of those in which the thought of death seems to have brought some genuine emotion'. Here she quotes from Bossuet's speech to the Duchesse de Fontanges in one of Landor's 'Imaginary Conversations':

[...] The beauty that has made a thousand hearts to beat one instant, at the succeeding has been without pulse and colour, without admirer, friend, companion, follower. She by whose eyes the march of victory shall have been directed, whose name shall have animated armies at the extremities of the earth, drops into one of its crevices and mingles with its dust. ${ }^{9}$

'How clear and stately', she concedes, 'yet how wearisome! Why? simply and crassly because there is no feeling in it at all'; -

it is all elaborately reasoned, planned out; and no man's reasoning and planning, however elaborate, can replace feeling. [...]

See how even in this passage he leaves the essential behind in order to work out a mere detail- "animated armies at the extremities of the earth, drops into one of its crevices and mingles with its dust." Why, the earth has become the heroine of this passage, and the poor dying beauty is a mere adjunct to its extension, its battlefields and holes and dust. "So she is," Landor might answer. But not to her own feelings, nor to ours, nor to Landor's, if he had any! (pp. 167-68).

Again the stately clarity is frankly conceded: if only the feeling were properly communicated, it would be a great achievement. Yet the final clause ('if he had any!') suggests not that the feeling is merely lost amid the overparticularities of the syntax, but that Landor lacked the feeling altogether. It is not simply an effect of his elaborate style that the feeling goes awry; rather, the stateliness of the style is, in Landor's case, the real aim, and takes up both his attention and that of his reader largely because there is no emotional aim to interfere with it. All his 'reasoning and planning', which, if marshalled to the service of a legitimate feeling, might have resulted in a triumph of technique, seems empty to Lee because it appears to be an end in itself, technique for its own sake and not for the conveyance of feeling. And the fact of its being so obviously 'planned out', premeditated, seems to her one of its main failings, removing it from the heightened state of emotion required by the subject. The 'beauty that has made a thousand hearts to beat' must take emotional precedence over 'the earth', the human over the inert.

\section{THE CLASSICAL MANNER}

In the two examples discussed above, Lee may be said to have approached the problem from the side of syntax; Landor's desire to plot out balanced sentences at the cost, or in the absence, of any emotional motivations, is the putative characteristic upon which she fastens. But, of course, it is more than a matter of syntax: it has to do

\footnotetext{
${ }^{8}$ From Landor's 'Pericles and Aspasia' (1836), letter xlvi. See The Complete Works of Walter Savage Landor, ed. T. Earle Welby and Stephen Wheeler, 16 vols (London 1927-36), vol. X, p. 33. Quoted in Lee, Handling of Words, p. 166; emphasis and parenthetical additions hers.

9 'Bossuet and the Duchess de Fontanges' (1828), Works of WSL, vol. VII, pp. 172-73.
} 
with the appropriateness of certain locutions to the particular matter in hand, judged from the point of view of 'feeling'. In other examples, she looks at the problem from a different angle, examining Landor's habits of treating 'objects'. Here the thing, the matter, is the prime focus, rather than the sentence structure. The author's prior relationship to his content is seen to have determined his syntax, and is diagnosed therefrom. The problem is the same, but now she is taking a more direct route through the 'artistic' characteristics, straight to the 'human' question of Landor's personal sense of his subject matter.

In this line of enquiry Lee allows herself the use of the 'arbitrary' but serviceable terms, Classical and Romantic. She is not referring, as one might suppose, to the 'Postscript' from Pater's Appreciations, but rather to Sidney Colvin's Selections from the Writings of Landor ${ }^{10}$ Colvin, who sees Landor as the type of the modern 'classical' writer, writes in his Preface about the distinction to be made between the romantic mode, 'with its thrilling uncertainties and its rich suggestions', and the classical manner, Landor's manner, which 'presents to us conceptions calmly realized in words that exactly define them, conceptions depending for their attraction not on their halo, but on themselves'. ${ }^{11}$ This is the definition, quoted by Lee, upon which she builds much of her argument; which is, briefly,-

\begin{abstract}
that these so-called classical ways of proceeding are more pretentious than efficient, that they are compatible with what is little better than verbiage, and that - one asserts it with awe-in Landor's own work they are indicative not of the great talent he really possessed, but of his melancholy limitations of soul and, therefore, lapses of sense. (p. 159).
\end{abstract}

The classic manner actually 'indicates' Landor's human, spiritual 'limitations', whilst at the same time profiting, as far as it may, from his mere technical 'talent'. This classical manner is evidently the way a person writes who is emotionally underdeveloped, yet highly cultured and sensitive to words. The conception of the 'classical' here employed is, as Lee tells us, borrowed from Colvin merely for argument's sake; it is quite at odds with her own use of the term elsewhere. To see the contrast, one has only to turn back to the dialogue-essay Orpheus in Rome (1894), where the 'classical' mode, exemplified by Gluck, is explained in terms of ideal emotional sanity, and so preferred over the 'romantic'. ${ }^{12}$ Following Colvin's meaning, however, she proceeds in the Landor essay to propose that, in the classical manner as thus determined, 'there seems to be some underlying belief that the aim of literature is to tackle, so far as possible, the famous Kantian "thing in itself," stripping it of such purely phenomenal wrappers and disguises as its effects.' Of course, in her particular choice of terms, Lee cannot help but call up more than a memory of Kant alone: she implicitly sets up a distinction, not necessarily an antagonism, between the Arnoldian position, according to which the critic must see 'the thing as in itself it really is', and the Paterian position, according to which the first duty of the aesthetic critic is to 'know one's impression as it really is'. ${ }^{13}$

And then, with her usual irony, she points out that the 'halo' of which Colvin speaks 'is evidently the value, the meaning which things occasionally take on owing

\footnotetext{
${ }^{10}$ Selections from the Writings of Landor, ed. Sidney Colvin (London 1882).

${ }^{11}$ Ibid., p. xiii. Quoted by Lee at p. 158; italics hers.

${ }^{12}$ Lee, 'Orpheus in Rome', in Althaea (London 1894) pp. 49-104.

${ }^{13}$ Pater, The Renaissance, Library edn (London 1910; first published 1873) p. viii. Also compare Lee's remarks with Pater's more measured discussion of the 'abstract' and 'particular', in 'The Doctrine of Plato', Part I, in Plato and Platonism, Library edn (London 1910; first published 1893) pp. 150-73; esp. p. 151.
} 
to their relations with poor human souls' (p. 159). With this sarcastic flourish Lee has reminded her readers of the values which to her own mind have always seemed uppermost. Things accrue 'value' and 'meaning' through their relations to the inner lives of people: the relation of the inner with the outer life, the objective with the subjective, is what most often seems to interest her, as it had interested Pater, who influenced her so deeply. ${ }^{14}$ This interest brought her, around the turn of the century, to her now much studied endorsement of psycho-physiological aesthetic 'empathy', 15 although the same basic problems of correlation between subject and object, self and 'otherness', had been a long-standing preoccupation, and formed, in parallel with the aesthetic theory, a basis of her ethical thought also. And without this sense of relationship - the 'halo' of subjectivity, the emotional associations which objects take from human experience and, in the 'empathic' process, stir up in aesthetic observers ${ }^{16}$ - the objects lose value, lose meaning, become divorced from 'feeling'.

In Pater the relation, often fortuitous, of an object or group of objects to the developing inner life of a person, or even of a phase of culture, is frequently its prime interest; -

\begin{abstract}
A book, like a person, has its fortunes with one; is lucky or unlucky in the precise moment of its falling in our way, and often by some happy accident counts with us for something more than its independent value. ${ }^{17}$
\end{abstract}

Such an observation must raise serious difficulties for those who would like criticism to be strictly empirical and to stand outside the play of 'happy accident'. But for Pater the value and meaning of certain things for certain people is often the point of entry into criticism, or else its final crowning theme, the realisation of it coming often in the form of some poignant observation or supposition which opens up the object to our interest. Lee, also, frequently finds in the imaginative act of sympathy with other people (especially the people of history) the necessary impulsion to see an object in the most appreciative way; works of art, places to which she travels, are generally given interest by human concerns and by relation to human affairs. In Hortus Vitae she can talk of her daily relationships with non-human others - animals, trees and buildings - as 'friendships', 'matured by conscious courtship on our part, retracing of steps day by day, and watching the friend's varying moods'. ${ }^{18}$ The manner which obliges literature to tackle the 'thing in itself', is fatally lacking in the human interest which confers meaning. Shucking things of their human values, The 'classical' writer is like a Sebastian van Storck ${ }^{19}$ in seeking after an 'objective' view of things, which is, in fact, abstract (because abstracted from real human experience), he fails in the moral and emotional spheres.

\footnotetext{
${ }^{14}$ For more on Lee's relationship to Pater, the reader should begin with Angela Leighton's chapter, 'Seeing Nothing: Vernon Lee's Ghostly Aesthetics', in On Form: Poetry, Aestheticism, and the Legacy of a Word (Oxford 2007, repr. 2008) pp. 99-124; or one of the following biographies: Peter Gunn, Vernon Lee (London 1964); Vineta Colby, Vernon Lee: A Literary Biography (Charlottesville 2003); Christa Zorn, Vernon Lee: Aesthetics, History, and the Victorian Female Intellectual (Athens, Ohio, 2003).

${ }^{15}$ Lee's theory of empathy was elaborated in Beauty and Ugliness, co-written with C. AnstrutherThomson (London 1912), and The Beautiful (Cambridge 1913).

${ }^{16}$ See Lee, The Beautiful, pp. 58-69 (esp. 65), 139-46, etc.

${ }^{17}$ Pater, Marius the Epicurean, Library edn (London 1910; first published 1885), vol. I, p. 93.

${ }^{18}$ Lee, 'Other Friendships', in Hortus Vitae, Week-End Library edn (London 1928; first published $1903)$ pp. $75-82$; p. 80.

${ }^{19}$ See Pater's story of this title in the Imaginary Portraits.
} 
Lee shares with Pater a kind of subjectivist humanism-subjectivist, yet committed to accuracy of perception and care for external realities. And in The Handling of Words, Pater's own literary style is contrasted almost directly with Landor's. In the chapter 'On Style', Lee had remarked that-

Pater stands half-way to Stevenson in the tendency to note rather the emotion caused by an object in himself than to reproduce the object and trust to its reproducing its impression. (p. 39).

Pater and Stevenson, writers particularly admired by Lee, present the subjective halo with the thing, or in its place; others present the thing itself and hope the reader will intuit the halo. Landor, in Lee's estimation, apparently falls outside both categories: he presents the thing without taking account of the halo, or chooses to present things which, as far as he is concerned, have no haloes.

Landor, therefore, has made his writing emotionally barren by presenting, in beautiful sentences, and with perfect clarity, objects of which the human 'values' and associations have been kept away, removed, or at least neglected. And yet, Lee goes on, -

there is in human nature such perverse hankering after relations between things and itself, that when the Writer, disdainful of halos, has stripped all things into isolation, he seems to be obliged to weave a new set of relationships [...] (p. 160).

Here she quotes from Landor's 'Imaginary Conversation' between 'Fra Lippo Lippi and Pope Eugenius the Fourth' (1846):

The clematis overtopped the lemon and orange trees; and the perennial pea sent forth here a pink blossom, here a purple, here a white one; and, after holding (as it were) a short conversation with the humbler plants, sprang up about an old cypress, played among its branches, and mitigated its gloom. White pigeons [...] examined me in every position their inquisitive eyes could take, [etc.] ${ }^{20}$

Her commentary follows:

The classical Writer's refusal to tell us how the perennial pea affected Lippi, the stylist's horror of saying that the perennial pea, merely was, has forced Landor, despite his singular sharpness of observation, into a number of amazing mis-statements [...] (p. 161).

The so-called 'classic manner' is so incompatible with human nature that Landor feels impelled to bring his objects into relationship with himself, and with human concerns, even though they have originally been conceived without any considerable measure of such feeling. Consequently he must engineer these relationships by mechanical means. Lee then takes the resulting conceits one by one and shows that they are inappropriate or inaccurate.

The main problem, the reason for this poverty of feeling and the consequent rhetorical figuration introduced to make up for it, is, she says, that-

Landor did not really care for what he was writing about, but only for the fact of writing. This is proved by his metaphors being not expressive, but explanatory; he has not felt the subject in those, or indeed in any, particular terms, but cast about him for parallels for better apprehension. (p. 167).

\footnotetext{
${ }^{20}$ See Works of WSL, vol. II, p. 297; but I have followed Lee's transcription (p. 160), with its slight variations of punctuation (and her italics).
} 
Landor's figurative language, not being governed by any real feeling, is applied arbitrarily. According to Ruskin, it may be useful to recall, the 'pathetic fallacy' is inexcusable unless the speaker should be in a state of heightened emotion; to commit the fallacy 'in cold blood'-Ruskin's phrase - is a stylistic fault. ${ }^{21}$ Lee appears to be making a similar complaint. Landor's imagery (which, in the case of the clematis and the perennial pea, is in fact an example of the pathetic fallacy, and of a kind Ruskin must have condemned) is concocted in cold blood; the conceits do not seem to have any basis in his, or his speaker's, real emotional apprehension of the objects; and, in fact, if he had experienced any real feeling towards these objects at all, then he would not have needed to invent such conceits in the first place.

In order to consolidate her argument, Lee produces another example, this time one which Colvin himself had discussed:

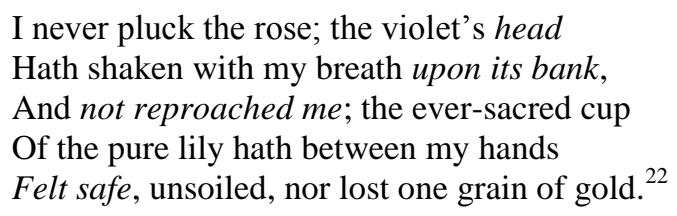

Here, she says, is 'the method which refuses all mere subjective halos, and makes for the "conceptions in themselves"' (p. 162). In this case the reader may be less ready to agree. After all, Landor, or his poetic persona, is speaking here in the first person about his personal relationship to a number of flowering plants, and there is, on the surface, plenty of emotive suggestiveness. Not enough for Lee. 'The lily', she says, 'was not allowed, of course, to stir Landor's fancy [...] It had to be considered for what it was! So, in order to be in legitimate relations to a verb, it was made to feel safe' (p. 162). In explaining the mental process which she thinks must have decided Landor's metaphor, Lee supposes both that Landor has been impelled by syntactical considerations (the need for a striking verb), and that he has been governed by the human demand to see inanimate objects in relation to human experience. Then comes the clinching sentence:

No one can complain that these flowers are presented through the halo of Landor's feelings, or that he had any feelings to present them through. (p. 163).

It is part of Lee's persona to overstate matters in this roguish way. She was, however, a precise writer even where most ironic. She does not actually say what at first she appears to be saying, that Landor had no feelings about anything, but only that he had no feeling through which to present the images of these flowers. That is, he had no feelings about the matter in hand, despite its having been of his own choosing.

\section{RHETORIC AND RHETORIC}

It is surely not a consistent quality of what we call, according to any of the other usual criteria, 'classical literature', that it presents objects without the 'halo' of subjective human associations. But when Lee observes with disapproval that, in finding metaphors, Landor seems not to have 'felt the subject in those, or indeed in any, particular terms, but cast about him for parallels', she would appear to be condemning

\footnotetext{
${ }^{21}$ See Ruskin, Modern Painters, vol. III (1856), ch. xii, esp. § 4-15.

22 'Faesulan Idyll', first published 1831, 11. 25-29. Works of WSL, vol. XVI (Poems IV), p. 6. Lee's emphasis; quoted at p. 162.
} 
a procedure or an attitude to writing which had been essential to the 'classical' theory and pedagogy of rhetoric - and, by extension, poetry - since ancient times, revived in the humanistic educational reforms of the Renaissance, and persisting strongly in classical education throughout the 'long' eighteenth century. The ancient rhetoricians and their early modern successors rarely give the impression that one's metaphors must come naturally, arise directly from one's real feeling for an object; the rhetorical manuals, on the whole, assume a level-headed exercise of reason in searching out the aptest figure. This 'cold-blooded' schoolroom approach is just what Lee finds so dissatisfying. 'I have watched Landor at work', she proclaims, after a passage of close reading:

Landor, even the mighty, severe demi-god of classic prose, has appeared to me in the semblance of a boy provided, by heartless teachers, with a theme, and obliged to provide a given number of lines thereon (p. 170).

If, therefore, the term 'classical' as used by Colvin, and so adopted in Lee's study, finds its best justification when considered in relation to the classical discipline of rhetoric, this only brings us back to the title Lee has given to the whole essay: 'The Rhetoric of Landor'. And whereas she takes up the term 'classic' from Colvin, the term 'rhetoric' is of her own choice, and deliberately foregrounded. She never exactly defines it, but it is clear enough that 'mere' rhetoric is to be distinguished from all writing founded upon genuine feeling: if one does not care for what one is writing about, but only for the fact of writing, then one is writing rhetorically. The 'rhetorical' and the 'poetic' would seem to have been at opposite ends of her scale, as we will see confirmed later.

'It is worth while examining and meditating on the merest technicalities of Landor's writings', she admits. 'His structure of sentences, for instance, is both musically and grammatically often a wonder' (p. 164). And there is some sensitive examination of particulars which show that she is willing to render up due tribute. 'These are high triumphs of literary craft', she concludes; 'but then everything, or nearly everything, in Landor is sacrificed to their attainment' (p. 165). The implication is that Landor's great talent was rhetorical; that, as the classical orator has topics supplied to him, not of his own choosing, and in certain cases (in the law courts, say, or the academic debate) may even be obliged to argue for positions not his own, so Landor, despite his free choice, appears unmoved by his own themes. His ingenuity cannot make poetry out of his materials, because he shows, in Lee's own phrase, 'the rhetorician's indifference' (p. 168).

And yet, discussing another passage of Landor, she makes the following observations:

What a struggle is here between reality and abstraction, and how in this confusion we utterly fail to know what to think, how to feel, fail utterly to receive the great Writer's word of command!

Now this word of command, or, if you prefer, this magician's spell, making our soul follow with docility, making it see, hear, feel solely what and in what manner the Writer chooses, can be given, I believe, on one condition only: that the Writer feel very distinctly the moods he wishes to impart, and see in a given light and in a given sequence the things he wishes us to look at. (p. 164).

From another point of view, this 'word of command' which to Lee's mind is the desideratum that can make all the difference, might easily be considered a distinctive function of RHETORIC. The idea that a poem or novel ought to make our soul follow 
with docility would be extremely unattractive to many modern critics and judicious devotees of serious 'literary' writing, used to the idea that poems should 'explore' and 'express' without preaching, without delivering simple emotional hits or sentimental messages; and that novels should present conflicting ideas and possibilities in all their complexity, without simply taking up a fixed position and leading the reader inexorably towards it. This attitude, reinforced in the twentieth century, is more than a passing fad; and in the later nineteenth century Walter Pater is unquestionably one of the greatest exponents of a literature of 'many-sidedness', or 'suspended judgement', both in his fictional and non-fictional prose. He, more perhaps than any other writer of comparable stature in the period, deliberately presents varying ideas and temperaments with sensitivity and sympathy, juxtaposing diverse perspectives without definitively espousing any one in particular, and always allowing for 'second thoughts'. And Vernon Lee generally follows him in this, using irony, dialogue and the 'essay' form to achieve, by different means, a similarly 'many-sided' view of things even in spite of the willfulness and waywardness of her literary voice. Yet here she is looking for the 'word of command' which tells us exactly how to feel.

In 1972 Donald Davie, incidentally (although perhaps not co-incidentally) one of Landor's most important critics in the twentieth century, published an essay entitled 'The Rhetoric of Emotion', in which, thinking primarily about contemporary poetry, he complained of a tendency for poets to aim primarily for the delivery of specific sentimental cues. Davie distinguishes between 'feeling' and 'emotion', and comes down firmly on the side of 'feeling':

Not only is feeling anchored in the immediacy of sensuous apprehension, tactile in the first place; but also, because it can mean 'groping', it fits those artifacts that we want to applaud as 'sensitive', as (precisely) tactful. ${ }^{23}$

'Emotion', on the other hand, implies that the the reader is being asked to 'emote' in a probably quite particular way, 'moved' in a certain direction, in response to particular 'stimuli'. Because emotion lacks the 'tentative exploratory character' thus ascribed to feeling, it provides 'no safeguard against sensationalism', and can too easily go along with the notion that the best art is that which provides the most intense emotion. ${ }^{24}$ In Davie's terms, the 'emotive' aim is what he calls 'rhetorical', producing literature which simply cues emotion in compliant consumers. Lee surely cannot be a reader as unsophisticated and obedient as those evoked by Davie. But when Davie laments that 'Our schoolchildren are trained to read poems as if they were coded signals giving them cues about what and how to feel', ${ }^{25}$ his idea of 'rhetoric' comes uncomfortably close to Lee's 'word of command'. And this power, in her view, is lacking in Landor just because he is too 'rhetorical' a writer. We appear to be faced with two entirely antithetical ideas of the rhetorical.

Turning for clarification to a later section of The Handling of Words, the chapter headed 'What Writers might Learn', we are forced to realise that finer distinctions are required, and that Lee and Davie are not so far apart as they might seem. She regrets that too much literature is really, upon inspection, only 'persuasion and exhortation in the guise of statement' (p. 304);-

\footnotetext{
${ }^{23}$ Donald Davie, 'The Rhetoric of Emotion', in With the Grain: Essays on Thomas Hardy and Modern British Poetry, ed. Clive Wilmer (Manchester 1998) pp. 324-30; p. 324.

${ }^{24}$ Ibid.

${ }^{25}$ Ibid., p. 326.
} 
the artistic processes of literature pretend to transfer facts and opinions from one man to the other, while most of the time they are merely transmitting orders how to act or at least how to feel. (p. 303).

Just here she is using nearly the same language as Davie, and making a similar point. This persuasive function of writing she considers a 'misuse' of 'literary power' ( $p$. 304), and both here and later she associates it with the war-mongering of the previous decade. ${ }^{26}$ Between this 'persuasion' and the 'rhetoric' ascribed to Landor, what, then, is the difference? The 'persuasive' writer, unlike Landor, does provide a word of command, and may very well be working upon the emotions; but whereas the poetic writer, like Landor, is expected to make us think and feel for the sake of thinking and feeling, for the sake of art which is an enhancer of life, the persuasive writer in Lee's sense is using language to alter opinion and affect the world of practical or political reality. Technique for its own sake is empty, but art, however closely determined by human characteristics and tied to human aims and moral life, must retain a degree of autonomy. The 'word of command' Lee approves is something which may enrich one's experience, potentially with lasting effect and not only in the moment of reading. Its function, however, is decidedly not the same as 'persuasion', i.e. that of 'making people feel and act differently from how those people might be prompted by their own circumstances and inclinations' (p. 306). Art-writing, in short, should not be a calculated effort to use words as an instrument of practical change in the opinions of its readers. Lee's own way of explaining this distinction is strikingly comparable with Davie's antithesis between 'emotion' and 'feeling'; for she distinguishes between two senses of the verb 'to sway':

\footnotetext{
'being swayed,' as we are swayed by music, architecture, the other visual arts, by lyric and dramatic poetry, and even the fine spectacles of Nature, is not the same kind of swaying as that by eminent statesmen, preachers, journalists, and even by plain men of letters, as exhibited, for instance, during the war years and all the other years since Man's Creation. (p. 307).
}

Instead of being made to bend to the persuasion of the writer, from 'Art' she wants to be swayed 'in the sense of being made to live, for however brief an interlude, according to the heart's desire, in the more vivid, steadier, essential and harmonious modes of its own invention, which means, of Art' (p. 307).

Davie distrusts 'emotion' for its own sake as the desired poetic experience. Lee distrusts particular kinds of emotion, strong or morbid ones especially, for purely artistic purposes; and indeed she does seem instictively to draw a line between emotion and feeling, contrasting them explicitly in her 1913 book The Beautiful, where she talks in one place of 'a feeling, sometimes amounting to an emotion', and later of 'feelings' as being 'rudiments of emotion'. ${ }^{27}$ In the early essay 'Chapelmaster Kreisler', too, she had argued, thinking primarily of music, that emotion could be no more than suggested, and must perforce be limited, by 'artistic form'- - which ought to 'please' and 'delight' rather than 'move' or 'tickle the nerves'. ${ }^{28}$ There, without holding the terms 'feeling' and 'emotion' apart from one another, she is at least separating the 'stormy reign of instinctive feeling' (akin to Davie's 'emotional'

\footnotetext{
${ }^{26}$ Compare Handling of Words, pp. 306-09, with Proteus: The Future of Intelligence (London 1925) pp. 45, 53, 57-59.

${ }^{27}$ Lee, The Beautiful, pp. 8, 42.

${ }^{28}$ Lee, 'Chapelmaster Kreisler', in Belcaro, 'New' $\left[3^{\text {rd }}\right]$ edn (London 1887; title first published 1881) pp. 106-28; pp. 120, 123, 125.
} 
sensationalism) from the 'serene' experience of the mind under the influence of art; ${ }^{29}$ and she defends the latter in the face of 'romantic' sentiments which prefer the former. This indicates her general inclinations. But then again, she expressly says that music is unlike poetry, ${ }^{30}$ and literature, she tells us, is the most 'emotional' art. ${ }^{31}$

Ultimately, Davie finds himself attracted, not without doubts and qualifications, to Landor's 'experiment' in restrained, 'classical' values, even if they were seldom achieved in the verse; - 'There is a certain magnificence in his obstinate wrong-headedness'. ${ }^{32}$ But Lee is left looking for a more convincing halo, more personalized sentiment, rejecting the values as well as the realization. She dislikes the sensation of being persuaded 'how to act' or 'how to feel' by rhetorical means, but her idea of poetic experience involves a willing surrender to a 'magician's spell' which tells you how to feel just for the time being, during the 'interlude' of the aesthetic response. One feels reasonably justified in adding 'and simply for those moments' sake, ${ }^{33}$ but with the proviso that, for both Lee and Pater, the worthwhile employment of individual moments in aesthetic experience ought to add up, or at least potentially contribute, to something of lasting value - a refinement of sensibility and sensitivity, in no amoral sense. But that is something quite different from, and perhaps opposed to, mere submission to the Persuasion that comes with outside motives. If Davie is suspicious of cheap thrills, so, elsewhere, is Lee; but here in The Handling of Words she is suspicious chiefly of argumentative opportunism, propaganda, brainwashing.

Lee, therefore, does not wish for anything as tawdry as a simple emotive signal for the sake of 'moving' the reader, tickling the nerves; but she does want a clear and efficient mechanism through which the writer, provided he or she does really have some feelings about the matter in hand, can let us know exactly what those feelings are, and elicit the same complex of feelings in the attentive reader. Given her concern with the 'human' value of literature, there is probably also an implied caveat, i.e. that the feelings must be of the right sort, too. If this last criterion is satisfied, she is more than content to be compelled, submissive to the will of the writer.

The passage from Landor which she cites with fullest approval shows how delicate a thing her 'word of command' could be. What she goes looking for is a note of the genuine, a hint, however subtle, of the human halo around the images presented. She catches up a footnote at the end of Landor's dialogue Leofric and Godiva (1829):

The story of Godiva, at one of whose festivals or fairs I was present in boyhood, has always interested me; and I wrote a poem on it, I remember, by the square foot [sic] at Rugby. [...] May the peppermint be still growing on the bank in that place! $!^{34}$

'How oddly simple,' says Lee, 'and how oddly like real poetry this is! Why? Because Landor was remembering his own past, and, once in a way, feeling genuine emotion' (p. 172). Her comment confirms the implied distinction between rhetoric and 'poetry', and she finds the latter in an ostensibly prosaic wisp of stray reminiscence. Here, at

\footnotetext{
${ }^{29}$ Ibid., pp. 122, 125.

${ }^{30}$ Ibid., p. 128.

${ }^{31}$ Handling of Words, pp. 35-36; also p. 31.

32 Davie, Purity of Diction in English Verse (London 1952), pp. 183, 196.

${ }^{33}$ The final words of the famous 'Conclusion' to Pater's Renaissance (p. 213).

${ }^{34}$ Works of WSL, vol. IV, p. 6. Landor's italics. Quoted by Lee at p. 172. 'Square foot' appears in all editions of The Handling of Words, but the correct reading is 'square pool'.
} 
last, she can feel that Landor has felt something. But there is nothing here for Davie to condemn.

\section{THE QUESTION OF 'FEELING'}

These appreciative remarks on Landor's footnote remind us that, in Lee's formulation, the essential 'word of command' can be communicated only on the condition that 'the Writer feel very distinctly the moods he wishes to impart.' This, perhaps, is the crux. In The Pentameron, his large-scale 'Imaginary Conversation' between Petrarch and Boccaccio, Landor places the following observation in the mouth of Boccaccio:

I have shed tears on writings which never cost the writer a sigh, but which occasioned him to rub the palms of his hands together, until they were ready to strike fire, with satisfaction at having overcome the difficulty of being tender. ${ }^{35}$

This passage is rightly singled out by Robert Pinsky, who remarks that 'Landor, a pure Romantic in so many other matters, here shocks us with a home truth about literary composition'. ${ }^{36}$ If the 'truth' is markedly not 'Romantic', is it Classical instead? The old distinction survives. At any rate, I concur with Pinsky's judgement that Boccaccio in this case is voicing a sentiment with which Landor would not have disagreed. But now, jumping at once to the other end of the spectrum, and to an author Lee found less perplexing, let us remember what D. G. Rossetti says about this matter in sonnet LXI of the 1881 House of Life:

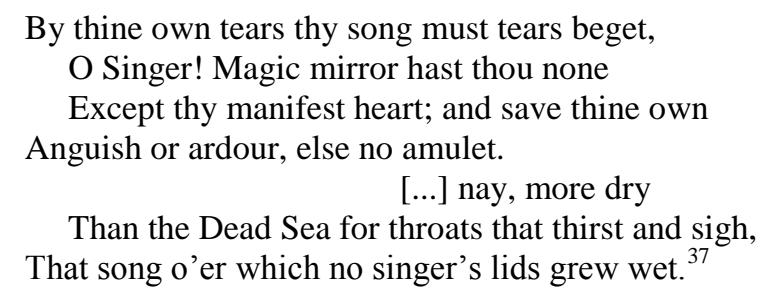

Poets, according to this poem, must actually feel the emotion they wish to convey; the 'manifest heart' must be apparent in the writing, and there is no magical amulet, no trick of the writer's craft, which can do the same work as genuine 'anguish or ardour'.

Landor's Boccaccio certainly suggests that the writer must think very carefully, must understand the feeling to be imparted; but he does not believe that the writer must actually feel the feeling prior to, or during, the difficult process of working out the best way to convey it. At first sight it might seem as though Lee were in full agreement with the Rossetti, and wholly at odds with the Landor. On reflection, we have no right to make such a definite assertion. What she says is that 'the Writer [must] feel very distinctly the moods he wishes to impart'. This does not mean that the writer must write directly from his own experience, or must limit his literary moods to those with which he is familiar in his 'real' life. If a writer should decide to evoke or depict a mood, a feeling, different from those which he himself (Lee's 'writer' is always given the masculine pronoun) has directly experienced, arising from situations in which he has never in fact been involved, but which, by an exercise of imagination

\footnotetext{
${ }^{35}$ Works of WSL, vol. IX, p. 247.

${ }^{36}$ Robert Pinsky, Landor's Poetry (Chicago 1968) p. 32.

${ }^{37}$ The Works of Dante Gabriel Rossetti, ed. William M. Rossetti, rev. edn (London 1911) p. 95.
} 
drawing upon his indirect, vicarious, sympathetic understandings of the experiences of those around him, he is able to realise sufficiently in himself in the moment of composition, then he would not be outside the parameters of Lee's stricture. All things considered, Lee is certainly much closer to Rossetti than to Landor in this regard; but Rossetti does seem to give priority to personal emotional experience, or autobiographical inspiration, and Lee does not. The distinction is important. Rossetti's position is also, we might note, more suitable to a writer primarily of lyric than to a dramatist or novelist.

Having glanced at the extremes, I would like to position Lee in relation to the writer with whom she has seemed, as far as this essay has been concerned, to share most. Walter Pater does not make any final pronouncements on this problem, although he does value the 'personal' and the 'sincere' in art, using these terms in broad and sophisticated senses, applicable to form as well as matter. Indeed one would not expect to find in him such an apparently dogmatic statement of the matter as Lee provides several times in the space of a short essay; their literary voices are fundamentally different, and Pater does not speak in the self-consciously and ironically obstinate tones which Lee made so characteristic and subtle an idiom. His most sustained consideration of the matter occurs in the lecture 'Plato and the Sophists' (1891-92), where, coyly quoting the 'intensely personal' Rossetti-without naming him - on the importance of the 'conception' or 'fundamental brainwork' in art, he plainly enough takes Plato's side in the debate 'Whether it is necessary, or even advantageous, for one who would be a good orator, or writer, a poet, a good artist generally, to know, and consciously to keep himself in contact with, the truth of his subject as he knows or feels it'. The better answer to this question is Yes. Plato in the Phaedrus is really concerned with 'truth' as opposed to vulgar opinion, but Pater characteristically makes room for subjectivity in the writer's 'sense' of truth ('as he knows or feels it'): the formal methods of art must not break from 'one's own vivid sensation or belief'; its 'mechanically communicable rules' must be sanctioned 'by the facts, by a clear apprehension of the facts'. ${ }^{38}$ Clarity does not convey 'apprehension' beyond the realm of subjectivity or relativism.

Pater shows a quite consistent preference for what might be called subjective reality as a basis for works of art. He would like to see the ideal style, not as 'caprice' or affectation, but as coincident with 'the man' only so far as it is dedicated to the 'absolutely sincere apprehension of what is most real to him'. ${ }^{39}$

The transcript of his sense of fact rather than the fact [...] Literary art, like all art which is in any way imitative or reproductive of fact-form, or colour, or incident - is the representation of such fact as connected with soul, of a specific personality, in its preferences, its volition and power. ${ }^{40}$

Pater seems to assume that the accomplished stylist (and he never spends much time writing about artists he does not admire) will always be composing in accord with inner and personal exigencies, with the subjective idea which determines success or failure by comparison with itself. The situation in which the writer might seek to convey a 'mood' without feeling it, does not seem to come into the question at all with him - except with regard to those 'sophists', and their rhetorical casuistries in the field of philosophy. This may be ascribed, at least in part, to the fact that Pater

\footnotetext{
${ }^{38}$ Plato and Platonism, pp. 99-123; pp. 116, 118-19.

${ }^{39}$ Appreciations, p. 36.

${ }^{40}$ Ibid., p. 10.
} 
generally does not make so strong a distinction as Lee between the matter and the form, and, if anything, attends primarily to the form as being the true measure and expression of what he calls the 'soul-fact'. ${ }^{41}$ In 'Plato and the Sophists', it is true, he speaks of the sophistic vice as a habit producing 'mere form without matter', but the terms are not emphatic, nor does he continue to run with them; and in any case he is speaking there on behalf of Plato. On the whole, he takes a less businesslike view of literary 'craft', by no means ignoring or degrading it, but thinking much less than Lee in terms of the 'things' or 'objects' of a piece of writing, which take priority in the compositional process and then must be treated in this or that manner; indeed, that way of proceeding might well seem closer to the sophistic method. Yes, 'the essence of all artistic beauty is expression', which 'cannot be where there's really nothing to express ' ${ }^{42}$ but the selectiveness and preferences involved in the form seem, for him, to have been sufficient evidence of the feeling bound up in the soul-fact, and he writes mainly about authors in whom the craft and the feeling are presumed inextricable. He mentions Landor only in passing, but it seems not unlikely that he would have considered Landor's style itself, the qualities Lee calls 'rhetorical', as the real objects of his feeling and 'preferences',- - rather than the clematis or perennial pea. This circumstance might not have seemed to him the great failing it seems to Lee, who wants to see the halo around the flower, not only around the words.

What is clear is that Lee shares with Pater a high valuation of subjectivity itself, of subjective views, of the 'human' concerns and associations which gather around things. Fact 'as modified by human presence', Pater says, is the 'matter of imaginative or artistic literature'. ${ }^{43}$ The soul-fact is what Lee is looking for amid the merely prosaic facts of Landor's garden plants, and she finds it only in the peppermint at Rugby - in the brief flicker of an apparently casual footnote-where for once the object and the feeling surrounding it both strike her as equally real, and are fully conjoined.

The Handling of Words did not appear as a whole volume until 1923 — only a year away from such a milestone of 'modern' critical theory as I.A. Richards' Principles of Literary Criticism (1924), in which Lee herself is mentioned more than once, in slightly arch tones. ${ }^{44}$ She clearly belonged to the old guard, and yet was still important enough to warrant attention. Richards has evidently read The Beautiful with some interest, although he has remembered or paraphrased it with deficient care. ${ }^{45}$

Lee's complaints about Landor do not align her with any particular group of critics or readers, nor do they conveniently place her as a 'type' within a particular historical moment. We have seen that she both learned and departed from Paterian values; and her fastidious and often quantitative literary analysis distinguishes her manner from that of most of the Victorian and Edwardian literary critics who immediately come to mind as her contemporaries. Landor had been a familiar author, widely admired, in the cultural world to which Lee had belonged. His reputation in Anglophone literary circles had remained generally high throughout the nineteenth century, and was renewed in the Nineties, when his stately classical restraint became a

\footnotetext{
${ }^{41}$ Ibid., p. 11.

42 Plato and Platonism, pp. 118, 120.

${ }^{43}$ Appreciations, p. 10.

${ }^{44}$ I.A. Richards, Principles of Literary Criticism, $2^{\text {nd }}$ edn (London 1960; first published 1924, rev. 1926) pp. 6, 13-14, 108-09.

${ }^{45}$ Cf. Leighton, On Form, pp. 102 ff., esp. 104-05: 'His misreading of Lee is a carelessness almost amounting to wilful blindness'.
} 
marmoreal ideal for many young writers of lyric attempting to curb their instincts for Pre-Raphaelite or Symbolist excesses. Although by the 1920s Landor was about to be subject to a sharp falling off in his popularity with a general 'literary' readership, nevertheless, from the Great War onwards, the intellectual atmosphere among serious critics and prominent literary mandarins, increasingly associated with the academy or with the modern poetry 'scene', was in many ways inhospitable to the attitude to literature that Lee had demonstrated in her finding fault with Landor. This was the world into which The Handling of Words was released, even if its readership was, as it must have been, somewhat different from that of the 'New Critics'. But the readership was far from entirely different: not only is she discussed in Richards' Principles, but my own first edition copy of her Proteus has marginalia from its original owner which tells me to 'cf. I. A. R' on several occasions.

Lee's rejection of Landor, superficially a sign of the times, also shows how vexed was her relationship, even if she little concerned herself with it, to the spirit of the ascendant 'New Criticism' and the values of Eliotic and Poundian Modernism. When Eliot complains about Swinburne's overwhelming interest in 'words', and supposed lack of interest in 'objects', he does not, in fact, seem very far away from Lee's objections to Landor. And indeed the notion of the 'objective correlative'correlating, that is, to subjective facts - is at bottom quite similar to the demand for objects with subjective haloes. ${ }^{46}$ Would The Waste Land or Pound's Cantos be possible, were it not for the assumption that the poet can infuse a range of disparate objects and allusions with personal feeling, and so transform and unify them? But Eliot's 'Impersonal theory of poetry', which argued that 'Impressions and experiences which are important for the man may take no place in the poetry, and those which become important in the poetry may play quite a negligible part in the man', ${ }^{47}$ shows an emphasis in the aesthetic ethic that implies impatience with the sort of demand Lee makes of Landor, even if in theory Lee might not have dismissed Eliot's claim outright. The doctrine of impersonality, which separates real feeling from poetic feeling, cannot easily accommodate Lee's position, even if only because it will not.

Pound was the pre-eminent critic of Landor in the 'Modernist' generation. Later in the century, his successor in that role was arguably Donald Davie. Both placed a high value on the quality of 'hardness' in poetry, a concept first elaboratednot exactly defined -in Pound's 1918 essay 'The Hard and Soft in French Poetry'. Landor was Pound's prime example of 'hardness in English', while a secondary example was Lionel Johnson, himself a Landorian enthusiast. ${ }^{48}$ Later, in his $A B C$ of Reading (1934), Pound spoke of the 'severe classical studies' that informed Landor's 'lapidary style'; and he drew a moral: 'A man preferring "a manner of writing" to the living language, runs considerable danger if he have not a culture as thorough as Landor's' ${ }^{49}$ This last point is likely to have given the hint to Davie, who wrote with some admiration about Landor's refusal of demotic diction - in effect, a refusal of the Wordsworthian theory of poetic language. For him, Landor was almost a tragic hero of poetic style, an upholder of classical 'urbanity' in the face of insuperable cultural

\footnotetext{
${ }^{46}$ T.S. Eliot, 'Swinburne as Poet' (1920) and 'Hamlet' (1919), in Selected Essays, $3{ }^{\text {rd }}$ rev. edn (London 1951, repr. 1999) pp. 323-27 and 141-46 respectively. And cf. Pater, Appreciations, p. 30, on 'correlatives'.

${ }^{47}$ Eliot, 'Tradition and the Individual Talent', Selected Essays, pp. 13-22; p. 20.

${ }^{48}$ Literary Essays of Ezra Pound, ed. T. S. Eliot (London 1954, repr. 1960) pp. 285-89; p. 286.

${ }^{49}$ Pound, ABC of Reading (New York 2010; first published 1934) p. 185.
} 
change; and although Davie's judgement is harsh, his attraction to the supposed ideal is felt in almost every paragraph. ${ }^{50}$

Where Eliotic 'impersonality' and Poundian 'hardness' were governing values in the formation of literary taste, and in the methods and inclinations of literary criticism, Vernon Lee's demand for 'feeling', not only in the writing but in the writer; her pursuit of the subjective 'human' interest around all objects and themes, together with her defence of the critic's right and responsibility, having first detected the 'human' aspect of the artwork, to subject that aspect to normal moral laws of her own choosing, judging the 'man' as a component of his own creations; - these demands and assumptions, exhibited in her colloquial belletrist style, were bound to look oldfashioned, even sentimental. Pound's 'hardness', like many of Eliot's basic values, ${ }^{51}$ reaches back into the nineteenth century, it is true; but largely to the areas of culture towards which Lee had always tended to take a sceptical attitude: Symbolism and 'decadence'. Unlike Arthur Symons, whose reputation was rescued for the Modernist generation precisely because of such cultural affiliations, disowned by Lee, - and of course quite unlike Yeats, who had soaked up the reverence for Landor current in the years of the Rhymers' Club,-Vernon Lee came to be seen increasingly as a kind of Victorian survivor. Or worse, a survivalist. At one point in 'The Rhetoric of Landor', she makes a humorous comment about 'the bad taste of a man born, after all, in the eighteenth century' (p. 173). If Landor, in the reign of Victoria, seemed a belated Augustan, Vernon Lee in the 1920s was, to many readers both sympathetic and dismissive, no less a representative of the preceding century.

\footnotetext{
${ }^{50}$ Davie, Purity of Diction, ch. 5, 'Landor's Shorter Poems' (pp. 183-96); and the later, more appreciative essay 'Attending to Landor' (1984), in Older Masters (Manchester 1992) pp. 305-14.

${ }^{51}$ Pater, too, spoke of the 'impersonality' of style (see Appreciations, p. 37; also the essay on 'Prosper Mérimée', collected in the Miscellaneous Studies).
} 